\title{
CHANGES IN GUT MICROBIOTA COMPOSITION AND THEIR ASSOCIATIONS WITH CORTISOL, MELATONIN AND INTERLEUKIN 6 IN PATIENTS WITH CHRONIC INSOMNIA
}

Masyutina AA, Gumenyuk LN $\bowtie$, Fatovenko YuV, Sorokina LE, Bayramova SS, Alekseenko Al, Shavrov YuV, Romanova AA, Seydametova DI

Vernadsky Crimean Federal University, Simferopol, Russia

The relationship between the gut microbiota and chronic insomnia remains understudied. The aim of this paper was to investigate changes in the taxonomic composition of the gut microbiota and their associations with the levels of cortisol, melatonin and IL6 in patients with chronic insomnia. Our comparative prospective cross-sectional study enrolled 55 patients with chronic insomnia, who formed the main group (female patients: $58.2 \%$, male patients: $41.8 \%$; mean age $31.6 \pm 7.4$ years), and 50 healthy volunteers, who comprised the control group (females: $68.0 \%$, males: $32.0 \%$; mean age $33.2 \pm 6.6$ years). The taxonomic composition of the gut microbiota was profiled using $16 \mathrm{~S}$ rRNA gene sequencing. Plasma cortisol and IL 6 and urine melatonin were measured by means of ELISA. Sleep quality was evaluated using the Pittsburgh Sleep Quality Index (PSQI). In patients with chronic insomnia, the abundance of Faecalibacterium ( $p=0.048$ ), Prevotella 9 $(p<0.001)$ and Lachnospira $(p=0.036)$ was lower, whereas the abundance of Blautia $(p=0.012)$ and Eubacteriumhallii $(p=0.003)$ was higher than in healthy volunteers. Significant correlations were established between the levels of IL6 and the abundance of Faecalibacterium $(r=-0.44 ; p=0.001)$ and Blautia $(r=0.42$; $p<0.001)$, as well as between cortisol concentrations and the abundance of Lachnospira $(r=-0.41 ; p=0.048)$. The abundance of Faecalibacterium and Blautiac was correlated with higher PSQI $(r=-0.47, p=0.001 ; r=0.45, p<0.001$, respectively). Our study contributed to the pool of data about changes in the gut microbiota and their associations with some endocrine and inflammation markers in patients with chronic insomnia. These data can be exploited to propose new strategies for the diagnosis and personalized treatment of insomnia aimed at normalizing the patient's gut microbiota.

Keywords: insomnia, gut microbiota, gut-brain axis, cortisol, melatonin, IL6

Author contribution: Masyutina AA, Fatovenko YuV collected, analyzed and interpreted the obtained data; Gumenyuk LN proposed the concept and design for the study; Sorokina LE, Bayramova SS, Alekseenko AA performed statistical analysis; Shavrov YuV, Romanova AA, Seydametova DI wrote the manuscript.

Compliance with ethical standards: the study was approved by the Ethics Committee of Georgievsky Medical Academy (Protocol № 10 dated November 16, 2020) and complied with the Declaration of Helsinki. Voluntary informed consent was obtained from all study participants.

$\square$ Correspondence should be addressed: Lesya N. Gumenuk

Lenin boulevard, 5/7, Simferopol, Republic of Crimea, 295006; lesya_gymenyuk@mail.ru

Received: 07.03.2021 Accepted: 14.04.2021 Published online: 27.04.2021

DOI: 10.24075/brsmu.2021.017

\section{ИЗМЕНЕНИЯ МИКРОБИОТЫ КИШЕЧНИКА И ИХ СВЯЗЬ С КОРТИЗОЛОМ, МЕЛАТОНИНОМ И ИНТЕРЛЕЙКИНОМ-6 У ЛИЦ С ХРОНИЧЕСКОЙ ИНСОМНИЕЙ}

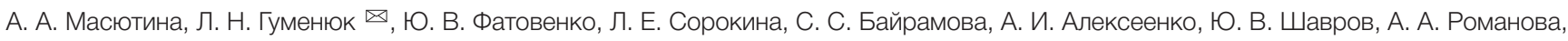
Д. И. Сейдаметова

Крымский федеральный университет имени В. И. Вернадского, Симферополь, Россия

На сегодняшний день актуальной остается проблема взаимосвязи микробиоты кишечника и хронической инсомнии. Целью исследования было изучить изменения таксономического состава микробиоты кишечника и характер их взаимосвязи с кортизолом, мелатонином и IL6 у лиц с хронической инсомнией. В одномоментном сравнительном проспективном исследовании приняли участие 55 лиц с хронической инсомнией (основная группа: женщины - 58,2\%, мужчины - 41,8\%; средний возраст — 31,6 \pm 7,4 лет) и 50 лиц без инсомнии (контрольная группа: женщины — 68,0\%, мужчины — 32,0\%; средний возраст - 33,2 \pm 6,6 лет). Оценивали таксономический состав микробиоты кишечника методом секвенирования гена 16S rRNA Определяли уровни кортизола и IL6 в плазме крови, мелатонина в моче с помощью иммуноферментного анализа. Для оценки качества сна использовали опросник PSQI. У лиц с хронической инсомнией обнаружены статистически значимое снижение численности Faecalibacterium (p = 0,048), Prevotella 9 ( $p<0,001)$ и Lachnospira ( $p=0,036)$ и повышение численности Blautia $(p=0,012)$ и Eubacteriumhallii $(p=0,003)$. Установлены статистически значимые корреляции значений IL6 с уровнем бактерий Faecalibacterium ( $r=-0,44 ; p=0,001)$ и Blautia $(r=0,42 ; p<0,001)$, концентрации кортизола и уровня бактерий Lachnospira ( $r=-0,41 ; p=0,048$ ). Выявлена сопряженность уровня бактерий Faecalibacterium, Blautiac c более высокими баллами по опроснику PSQI ( $r=-0,47, p=0,001 ; r=0,45, p<0,001$ соответственно). Таким образом, получены дополнительные данные об особенностях изменений микробиоты кишечника и их связи с некоторыми гормональными и воспалительными биомаркерами при хронической инсомнии, позволяющие применять новые терапевтические стратегии в персонифицированном лечении и диагностике инсомнии, направленные на нормализацию кишечной микробиоты.

Ключевые слова: инсомния, микробиота кишечника, ось «микробиота-кишечник-мозг», кортизол, мелатонин, IL6

Вклад авторов: А. А. Масютина, Ю. В. Фатовенко - сбор, анализ и интерпретация данных; Л. Н. Гуменюк - замысел и дизайн исследования; Л. Е. Сорокина, С. С. Байрамова, А. А. Алексеенко - статистическая обработка данных; Ю. В. Шавров, А. А. Романова, Д. И. Сейдаметова- подготовка статьи.

Соблюдение этических стандартов: исследование одобрено этическим комитетом Крымской медицинской академии имени С. И. Георгиевского (протокол № 10 от 16 ноября 2020 г.), проведено в соответствии с требованиями Хельсинкской декларации. Все лица, включенные в исследование, подписали добровольное информированное согласие.

$\bigotimes$ Для корреспонденции: Леся Николаевна Гуменюк

бульвар Ленина, 5/7, г. Симферополь, Республика Крым, 295006; lesya_gymenyuk@mail.ru

Статья получена: 07.03.2021 Статья принята к печати: 14.04.2021 Опубликована онлайн: 27.04.2021

DOI: $10.24075 /$ vrgmu.2021.017 
Insomnia is common in the general population and has multiple medical and social consequences [1, 2]. Today, insomnia is considered to be a psychobiological disorder associated with psychological, neuroendocrine, neuroimmune, electrophysiological, neurophysiological, structural, and functional changes in the body [3]. There is extensive discussion in the literature about the role of some biomarkers like cortisol [4], melatonin [5] and IL6 [6] in insomnia.

In recent years, there has been increasing evidence of the close interplay between the gut microbiota and the central nervous system; it occurs through the microbiota-gut-brain axis and has the central role in neuroimmunoendocrine interactions $[7,8]$. A number of experimental and clinical studies have demonstrated a relationship between the gut microbiota and sleep. For example, an interference with the normal sleep pattern of laboratory mice caused changes to the composition and diversity of their gut microbiota [9]. Similar changes were observed in the gut microbiota of shift workers [10]. Another study reports that therapy for intestinal dysbiosis increases sleep duration and improves sleep efficiency [11-12]. However, many aspects of the relationship between the gut microbiota and inflammation/endocrine markers in the setting of chronic insomnia remain understudied. There are no published data on the association between the gut microbiota and cortisol levels in patients with chronic insomnia.

According to some publications, insomnia induces a systemic hypoergic inflammatory response characterized by elevated proinflammatory cytokines. One of such cytokines is IL6; it is recognized by some authors as an important somnogenic factor [13]. Elevated serum IL6 has been negatively correlated with the self-reported quality of sleep in insomniacs [6]. A few studies point to an association between gut dysbiosis and the levels of IL6 $[13,14]$. However, the impact of microbiota composition on IL6 concentrations is not transparent due to conflicting data. For example, the abundance of Proteobacteria has been positively correlated with IL6 levels in insomniac men [13]. In another study, an association has been established between plasma IL6 concentrations and the abundance of Faecalibacterium and Blautia in the gut microbiota of patients with chronic insomnia [14]. So, the relationship between the gut microbiota and chronic insomnia requires further elucidation.

The aim of this study was to investigate the taxonomic composition of the gut microbiota and their associations with the levels of cortisol, melatonin and IL6 in patients with chronic insomnia.

\section{METHODS}

This study was a comparative prospective cross-sectional study. Using the continuous sampling method, we selected 55 patients of the Somnology Center, Simferopol, with previously diagnosed chronic insomnia (the main group) and 50 healthy volunteers without insomnia (the control group) who presented for an annual medical checkup at the Hemocode medical center, Simferopol, and were eligible for the study. The main group consisted of 32 female (58.2\%) and 23 male (41.8\%) patients; the mean age in this group was $31.6 \pm 7.4$ years. The control group (CG) included 34 healthy females (68.0\%) and 16 males (32.0\%); their mean age was $33.2 \pm 6.6$ years. The groups were comparable in terms of $\operatorname{sex}\left(p=0.95 ; \chi^{2}\right)$, age $\left(p=0.91 ; \chi^{2}\right)$ and body mass index $\left(p=0.055 ; \chi^{2}\right)$.

Inclusion criteria for patients: chronic insomnia lasting over 3 months, age of 18-45 years.

Exclusion criteria for patients: body temperature above $36.9^{\circ} \mathrm{C}$; types 1 or 2 diabetes mellitus; obesity; myocardial infarction; severe arrythmias; congestive heart failure; hypertensive heart disease; a past history of stroke or TIA; stroke within 6 months preceding the study; severe or decompensated comorbidities that could interfere with the patient's participation in the study or affect the outcome of the study; irritable bowel syndrome; chronic gastrointestinal or hepatic disorders; blood disorders; cancer; bacterial or viral infection; mycosis; constipation or diarrhea in the month preceding the study; psychiatric disorders; a past history of alcoholism or substance abuse; therapy with antibiotics, prebiotics, probiotics, symbiotics, antisecretory drugs, psychotropic drugs or any other medications capable of affecting sleep within 3 months preceding the study; intake of drugs that affect colonic function in the month preceding the study; psychotherapy for insomnia within 3 months preceding the study; shift work or working across time zones in the month preceding the study.

Inclusion criteria for healthy volunteers: age of 18-45 years; no depression according to the Patient Health Questionnaire-9 (PHQ-9 score < 5 points); no anxiety according to $\mathrm{PHQ}$ and Generalized Anxiety Disorder-7 scale ( $<5$ points); no somatoform disorders (PHQ-15 $<5$ points); no chronic conditions or allergies; no infections or acute conditions within 2 months preceding the study; no constipation or diarrhea in the month preceding the study; no shift work or jobs involving travelling across time zones in the month preceding the study; no therapy with prebiotics, probiotics or symbiotics within 3 months preceding the study; no therapy affecting colonic function in the month before the study; no past history of psychiatric disorders, alcoholism or drug addiction; voluntary informed consent to participate.

Exclusion criteria for healthy volunteers: body temperature above $36.9{ }^{\circ} \mathrm{C}$; shift work or jobs involving travelling across time zones in the month preceding the study.

Insomnia was diagnosed according to the criteria of the International Classification of Sleep disorders, ver. 3 (2014) [15]. The quality of sleep was assessed using the Pittsburgh Sleep Quality Index (PSQI) [16]. The severity of insomnia was assessed using the Insomnia Severity Index (ISI) [16].

To analyze the taxonomic composition of the gut microbiota, stool samples were collected in the morning (from 8.00 to $11.00 \mathrm{am}$ ), then frozen and stored in disposable plastic containers at $-80{ }^{\circ} \mathrm{C}$ until further use for the metagenomic analysis. Total DNA extraction was performed by means of phenol extraction. The nucleotide sequence of the extracted DNA was determined by shotgun sequencing; the procedure was carried out using a high-throughput SOLiD5500 Wildfire instrument (Applied Biosystems; USA) [17].

The obtained reads were filtered and taxonomically classified in QIIME ver. 1.9.1 (Caporaso labs; USA) [18]. The approach employed for taxonomic profiling involved the use of 2 taxonomic databases. First, a reference dataset of operational taxonomic units (OUTs) was selected by comparing the yielded 16S rRNA reads with GreenGenes data, ver. 13.5 [19]. Then, the RDP algorithm was applied to assign an appropriate taxonomic group to the OUT data using the human intestinal microbiota 16S rRNA database (HITdb) as a reference [20].

The abundance and diversity of the patients' gut microbiota was studied through the identification of microbial species, genera and phyla. The $\alpha$-diversity of the microbial community was assessed based on the values of Chao1, Sobs (the number of species observed in the studied sample) and ACE (Abundance-based Coverage Estimator); all calculations were performed in Mothur v.1.22.0 (http:// www.mothur.org).

Serum levels of cortisol and IL6 were measured using ELISA assays (Vector-Best; Novosibirsk; Russia). Fasting peripheral 
blood was collected in the morning (7:00-9:00) after at least 15 minutes of rest.

Melatonin production was measured from the excretion of its major metabolite, 6-sulfatoxymelatonin (aMT6s) in night (6:00) and day (20:00) urine using ELISA assays (Buhlmann; Switzerland). The samples were processed in a semi-automated StatFax 2100 analyzer (Awareness Technology; USA). Test tubes containing the collected blood and urine samples were stored at $-20^{\circ} \mathrm{C}$.

Statistical analysis was carried out in STATISTICA 8.0 (StatSoft. Inc.; USA). For normally distributed variables, means and standard deviations were calculated; for nonnormally distributed variables, medians, Q1 and Q3 values were determined. The normality of data distribution was tested using a Gaussian distribution test. For categorical variables, percentages and absolute quantities were calculated. Normally distributed quantitative variables were compared using the parametric Student's t-test. For non-normally distributed variables, the Mann-Whitney U-test was applied. Categorical variables were compared using the chi-square test. To assess the correlation between the studied variables, Spearman's correlation coefficient was applied. Differences were considered significant at $p<0.05$. In addition, correlation analysis and multiple rank correlation analysis were carried out; the validity of correlations was tested using tables of critical values.

\section{RESULTS}

Participant characteristics are provided in Table 1. In the main group, the duration of insomnia varied from 5 months to 3.5 years and was $1.7[1.1 ; 2.4]$ years on average. Twenty-one patients $(38.6 \%)$ from the main group had a past history of therapy for insomnia. Of them, plant-derived sedatives had been tried by 10 patients (47.6\%); 8 (38.1\%) patients had tried melatonin-based medications and 3 patients (14.3\%) had undergone psychotherapy.

While studying the taxonomic composition of the gut microbiota, we found the $\alpha$-diversity of the microbial community was much poorer in patients with chronic insomnia than in healthy volunteers (based on Chao1; $p=0.016$ ). ACE and Sobs values were slightly lower in the main group but these differences were insignificant $p=0.054$ and $p=0.052$, respectively; Fig. 1). However, the groups differed significantly in terms of Actinobacteria abundance: these microorganisms were more abundant in patients with chronic insomnia than in healthy volunteers $(p=0.0003)$.

At the genus level, the gut microbiota of patients with insomnia was characterized by a significant reduction in the abundance of Faecalibacterium $(p=0.048)$, Prevotella 9 ( $p=0.0002)$ and Lachnospira $(p=0.036)$, as compared to

Table 1. Characteristics of the participants with and without insomnia the control group, and a more abundant population of Blautia $(p=0.012)$ and Eubacterium hallii $(p=0.003)$ (Fig. 2).

The serum levels of IL6 and cortisol were significantly higher in patients with insomnia than in the control group. Melatonin levels were lower in the control group, but the differences between the groups were insignificant (Table 2).

The analysis of the relationship between the composition of the gut microbiota and inflammation/endocrine markers revealed significant correlations between IL6 levels and the abundance of Faecalibacterium ( $r=-0.44 ; p=0.001)$ and Blautia ( $r=0.42 ; p<0.001$ ), as well as between cortisol levels and the abundance of Lachnospira ( $r=-0.41 ; p=0.048)$.

The correlation analysis revealed a correlation between the abundance of Faecalibacterium and Blautia and higher PSQI $(r=-0.47, p=0.001 ; r=0.45, p<0.001$, respectively) and higher ISI scores $(r=-0.51, p=0.002 ; r=0.48$, $p<0.001$, respectively). The abundance of Faecalibacterium was negatively correlated with higher depression scores $(r=-0.44 ; p<0.001)$, whereas the abundance of Lachnospira was negatively correlated with higher anxiety scores $(r=-0.51$; $p<0.001)$ and higher ISI $(r=-0.52 ; p<0.001)$.

Significant correlations were established between the levels of IL6 and the abundance of Faecalibacterium ( $r=-0.44$; $p=0.001)$ and Blautia $(r=0.42 ; p<0.001)$. In addition, we were able to establish a correlation between the abundance of some bacteria (Faecalibacterium, Blautia) and the quality of sleep on the PSQI scale $(r=0.37 ; p=0.001 ; r=0.54$; $p=0.011$, respectively). The severity of insomnia (the total ISI score) was directly correlated with the abundance of these bacteria ( $r=0.67 ; p=0.005 ; r=0.29 ; p=0.0001$, respectively). The severity of depression on the PHQ-9 scale was correlated with the abundance of Faecalibacterium and Blautia $(r=0.19$; $p=0.005 ; r=0.32 ; p=0.003$, respectively). Cortisol levels were correlated with the abundance of Lachnospira and the severity of insomnia on the ISI scale $(r=0.37 ; p=0.002)$.

Besides, a correlation was discovered between the abundance of Lachnospira and higher ISI $(r=-0.38$; $p<0.001)$ and GAD-7 scores $(r=-0.47 ; p<0.0001)$.

\section{DISCUSSION}

A promising area of research, the metabolic integration between the gut microbiota and the brain implemented via the gut-brain axis is the central element of neuroimmunoendocrine interactions [21]. Today, many researchers hold the opinion that the gut microbiota plays a significant role in psychiatric disorders and homeostatic imbalance [22, 23]. Some studies have demonstrated an association between the gut microbiota and sleep. For instance, changes to a sleeping schedule were reported to induce changes in the composition of the gut

\begin{tabular}{|l|c|c|}
\hline \multicolumn{1}{|c|}{ Parameter } & $\begin{array}{c}\text { Man group } \\
(n=55)\end{array}$ & $\begin{array}{c}\text { Control group } \\
(n=50)\end{array}$ \\
\hline Women / men $(n, \%)$ & $32(58.2) / 23(41.8)$ & $34(68.0) / 16(32.0 \%)$ \\
\hline Mean age, years $(\mathrm{M} \pm \mathrm{CD})$ & $31.6 \pm 7.4$ & $33.2 \pm 6.6$ \\
\hline Body mass index, $\mathrm{kg} / \mathrm{m}^{2}$ & $25.2 \pm 4.4$ & $25.6 \pm 3.9$ \\
\hline PSQI & $15.4 \pm 3.7^{\star}$ & $3.3 \pm 1.4$ \\
\hline ISI, points & $5.3[3.6 ; 6.4]$ & $13.2[10.4 ; 16.7]$ \\
\hline PHQ-9 & $9.1 \pm 4.2^{*}$ & $3.4 \pm 1.2$ \\
\hline GAD-7 & $7.9 \pm 4.5^{\star}$ & $2.9 \pm 1.3$ \\
\hline PHQ-15 & $9.9 \pm 3.2^{*}$ & $3.3 \pm 1.5$ \\
\hline
\end{tabular}

Note: ${ }^{*}-p<0.001$ relative to CG, ISI — Insomnia Severity Index. 

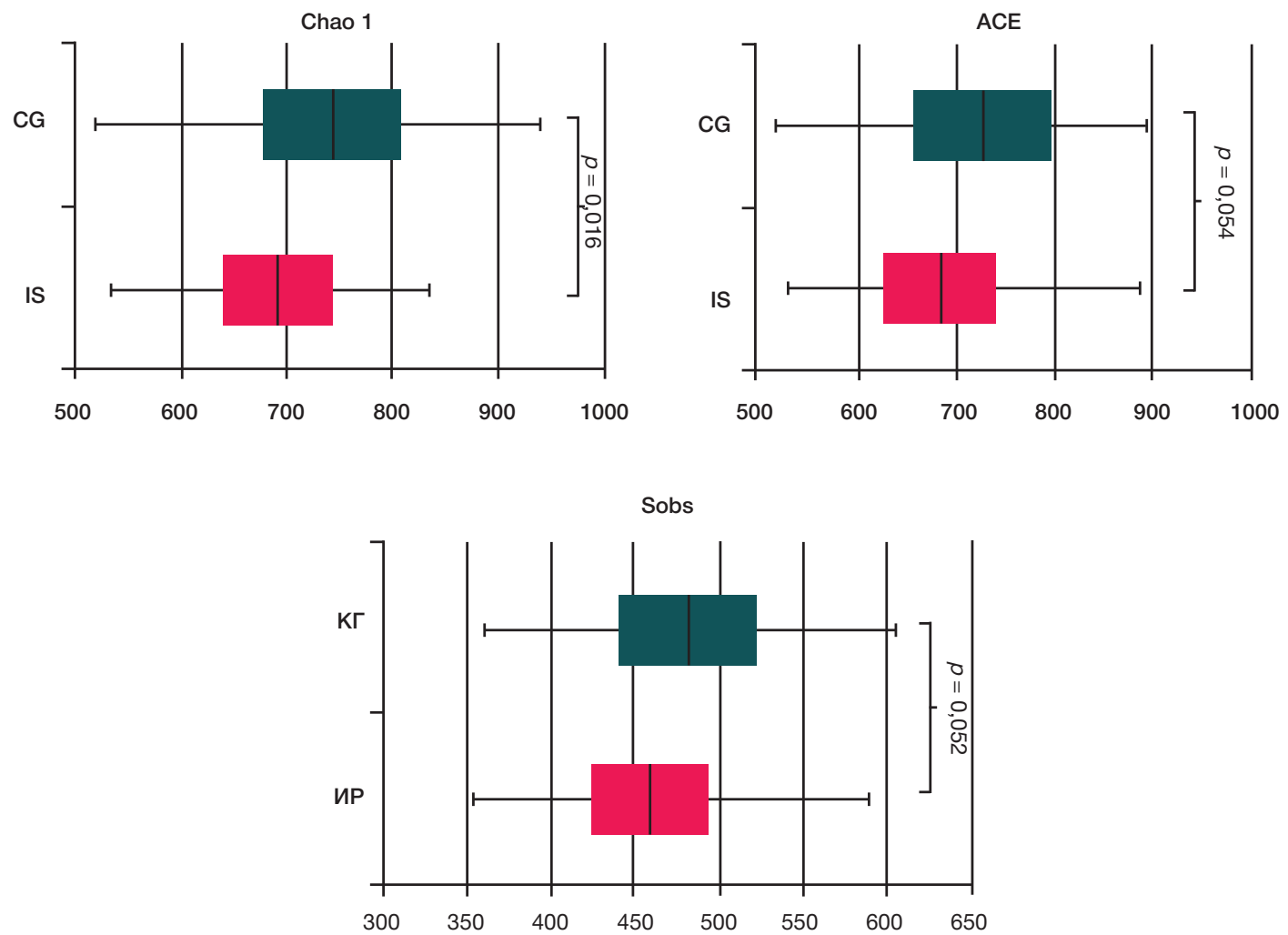

Fig. 1. Comparison of the gut microbiota composition at the phylum level between patients with insomnia and healthy volunteers. IS — insomnia, CG — control group

microbiota [9]. In another study, therapy for intestinal dysbiosis increased sleep duration and sleep efficiency [11]. At the same time, many aspects of the relationship between the gut microbiota and endocrine/inflammation markers in patients with chronic insomnia remain understudied.

Our study demonstrates that the composition of the gut microbiota differs significantly between patients suffering from chronic insomnia and healthy individuals. Specifically, the bacterial $\alpha$-diversity was poorer in patients with chronic insomnia. This finding was confirmed by lower Chao1 index in such patients and is consistent with the results of an earlier study [24]. In patients with chronic insomnia, the population of anaerobic Faecalibacterium, Prevotella 9 and Lachnospira that

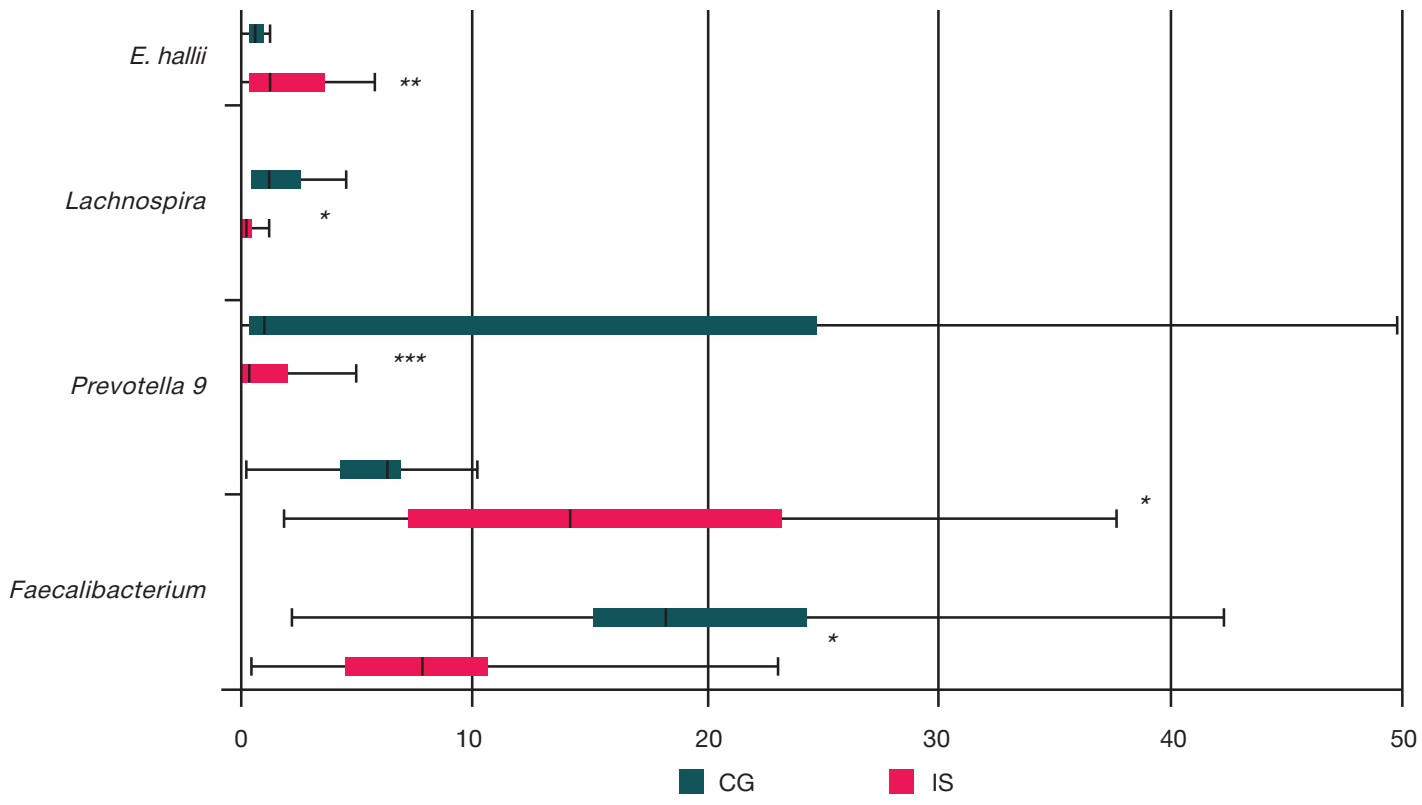

Fig. 2. Comparison of the gut microbiota composition at the genus level between patients with insomnia and healthy volunteers. IS — insomnia CG — control group 
Table 2. Inflammation and endocrine markers in patients with insomnia and healthy volunteers (mean \pm SD)

\begin{tabular}{|l|c|c|c|}
\hline \multicolumn{1}{|c|}{ Parameter } & $\begin{array}{c}\text { Main group } \\
n=55\end{array}$ & $\begin{array}{c}\text { Control group } \\
n=50\end{array}$ & $p$ \\
\hline Cortisol, $\mathrm{nmol} / \mathrm{L}$ & $581.5 \pm 110.6$ & $323.5 \pm 108.1$ & $p=0.036$ \\
\hline Melatonin (8:00), pg/ml & $12.2 \pm 2.4$ & $13.8 \pm 2.6$ & $p=0.652$ \\
\hline Melatonin (20:00), pg/ml & $3.5 \pm 1.2$ & $4.4 \pm 1.1$ & $p=0.581$ \\
\hline IL6, $\mathrm{pg} / \mathrm{ml}$ & $5.6 \pm 0.9$ & $2.8 \pm 0.8$ & $p=0.014$ \\
\hline
\end{tabular}

$43.5 \pm 6.9$ years in the study of our colleagues. Besides, we did not include patients with psychiatric disorders in order to negate their effect on the results of the study, whereas our colleagues did not specify psychiatric disorders as an exclusion criterion.

The established correlation between the reduced abundance of Faecalibacterium, the increased abundance of Blautia and higher PSQI and ISI scores leads us to hypothesize that changes in the abundance of these bacteria are typical for patients with chronic insomnia. It is also possible that an expansion of the Faecalibacterium population and a shrinkage of the Blautia population induced by therapy mitigates insomnia. Further research is necessary to test this hypothesis.

The analysis of endocrine and inflammation markers revealed that serum cortisol and IL6 levels differed significantly between patients with chronic insomnia and healthy volunteers. These two biomarkers were significantly correlated with the abundance of some bacteria inhabiting the intestine, suggesting an association between sleep disorders and the composition of gut microbiota. For example, negative correlations were established between cortisol levels and the abundance of Lachnospira. These findings contradict the results of another study which reported the lack of significant correlations between cortisol levels and gut microbiota diversity in patients with insomnia [13]. The lack of consistency between these two sets of data might be explained by the fact that our sample included individuals of both sexes, whereas in the study of our colleagues [13] the sample was all-male. This suggests the existence of sex-related differences in the association between cortisol levels and the composition of gut microbiota. Further research is needed to elucidate this problem.

Our study did not confirm the correlation between aMT6s excretion and changes in the microbiota composition in patients with chronic insomnia. While analyzing the literature, we did not find any publications that explored this problem in a sample of patients with chronic insomnia. However, there is evidence about the role of melatonin in regulating the composition of the gut microbiota [27]. In the cited study, melatonin concentrations were measured from urine aMT6s, which, in turn, characterizes secretion of melatonin by the pineal gland [28], whereas in an earlier study [29] the authors focused on enteral melatonin in the gastrointestinal tract produced by enterochromaffin intestinal cells.

Chronic inflammation might be an important pathogenic link between the gut microbiota and sleep. For example, it has been demonstrated that chronic sleep deprivation is associated with elevated plasma IL6 [30]. In another study, sleep duration was directly correlated with plasma IL6 [31]. Intestinal dysbiosis may trigger inflammatory immune response accompanied by elevated systemic proinflammatory cytokines. Established in [14], the correlation between the levels of IL6 and the abundance of Faecalibacterium and Blautiay in patients with chronic insomnia was confirmed by our study, suggesting a significant role of these bacteria in maintaining inflammation and aggravating insomnia and its consequence. Despite the fact that the role of Blautia in the development of inflammation has been proved, data on their association are contradictory. Some authors report a direct correlation between the abundance of Blautia and inflammatory dysregulation [32], others state that the correlation is negative [33]. According to our study, an expansion in the Blautia population promotes increased plasma IL6. Importantly, we analyzed the level of one proinflammatory cytokine only and so cannot provide the characterization of the overall inflammatory status in patients with chronic insomnia.

\section{CONCLUSIONS}

The gut microbiota of patients with chronic insomnia is characterized by pronounced changes in its taxonomic composition and microbial abundance. Significant correlations observed between some representatives of the gut microbiota and PSQI, endocrine and inflammation markers support the concept of the association between the composition of the gut microbiota, the abundance of its members and chronic insomnia. Further research is needed to confirm the role of the gut microbiota in the pathogenesis of chronic insomnia. The association between the composition of the gut microbiota and endocrine markers remains understudied. Therapy aimed at balancing the composition of the gut microbiota might improve the efficacy of therapy for chronic insomnia.

\section{References}

1. Mai E, Buysse DJ. Insomnia: prevalence, impact, pathogenesis, differential diagnosis, and evaluation. Sleep Med Clin. 2008; 3 (2): 167-174. DOI: 10.1016/j.jsmc.2008.02.001.

2. Ohayon MM. Epidemiology of insomnia: what we know and what we still need to learn. Sleep Med Rev. 2002; 6 (2): 97-111. DOI: 10.1053/smrv.2002.0186.

3. Levenson JC, Kay DB, Buysse DJ. The pathophysiology of insomnia. Chest, 2015, 147: 1179-1192. DOI: 10.1378/ chest.14-1617

4. Rodenbeck A, Hajak G. Neuroendocrine dysregulation in primary insomnia. Rev Neurol (Paris). 2001; 157 (11 Pt 2): S57-61.

5. Forrest CM, Mackay GM, Stoy N, Stone TW, Darlington LG.
Inflammatory status and kynurenine metabolism in rheumatoid arthritis treated with melatonin. Br J Clin Pharmacol. 2007; 64 (4): 517-26. DOI: 10.1111/j.1365-2125.2007.02911.x.

6. Hurtado-Alvarado G, Dominguez-Salazar E, Pavon L, VelazquezMoctezuma J, Gomez-Gonzalez B. Blood-brain barrier disruption induced by chronic sleep loss: low-grade inflammation may be the link. JImmunolRes. 2016; 2016 (4576012): 1-15. DOI: 10.1155/2016/4576012

7. Cryan JF, Dinan TG. Mind-altering microorganisms: the impact of the gut microbiota on brain and behaviour. Nat Rev Neurosci. 2012; 13 (10): 701-712. DOI: 10.1038/nrn3346.

8. Macpherson AJ, Harris NL. Interactions between commensal 
intestinal bacteria and the immune system. Nat Rev Immunol. 2004; 4 (6): 478-85. DOI: 10.1038/nri1373.

9. Thaiss CA, Levy M, Korem T. Microbiota diurnal rhythmicity programs host transcriptome oscillations. Cell. 2016; 167 (6): 1495-510.e12. DOI: 10.1016/j.cell.2016.11.003.

10. Reynolds AC, Paterson JL, Ferguson SA, Stanley D, Wright KP Jr, Dawson D. The shift work and health research agenda: considering changes in gut microbiota as a pathway linking shift work, sleep loss and circadian misalignment, and metabolic disease. Sleep Med Rev. 2017; 34: 3-9. DOI: 10.1016/j.smrv.2016.06.009.

11. Jackson ML, Butt H, Ball M, Lewis DP, Bruck D. Sleep quality and the treatment of intestinal microbiota imbalance in chronic fatigue syndrome: a pilot study. Sleep Sci. 2015; 8 (3): 124-33. DOI: 10.1016/j.slsci.2015.10.001.

12. Poroyko V, Carreras A, Khalyfa A, et al. Chronic Sleep Disruption Alters Gut Microbiota, Induces Systemic and Adipose Tissue Inflammation and Insulin Resistance in Mice. Sci Rep. 2016; 6: 35405. DOI: 10.1038/srep35405

13. Smith RP, Easson C, Lyle SM, et al. Gut microbiome diversity is associated with sleep physiology in humans. PLOS ONE. 2019; 14 (10): e0222394. Available from: https://doi.org/10.1371/ journal. pone.0222394/

14. Li Y, Zhang B, Zhou Y, Wang D, et al. Gut Microbiota Changes and Their Relationship with Inflammation in Patients with Acute and Chronic Insomnia. Nat Sci Sleep. 2020; 12: 895-905. Available from: https://doi.org/10.2147/NSS.S271927.

15. American Academy of Sleep Medicine. International classification of sleep disorders: Diagnostic and coding manual. Westchester, III.: American Academy of Sleep Medicine, 2014.

16. Buysse DJ, Reynolds CF, Monk TH, et al. The Pittsburgh sleep quality index: a new instrument for psychiatric practice and research. Psychiat Res. 1989; 28: 193-213.

17. Mitra S, Forster-Fromme K, Damms-Machado A, et al. Analysis of the intestinal microbiota using SOLiD16S rRNA gene sequencing and SOLiD shotgun sequencing. BMC Genomics. 2013; 14 (5): 16.

18. Caporaso JG, Kuczynski J, Stombaugh J, et al. QlIME allows analysis of high-throughput community sequencing data. Nat Methods. 2010; 7 (5): 335-36. DOI: 10.1038/ nmeth.f.303.

19. DeSantis, TZ, Hugenholtz P, Larsen N. Greengenes, a chimerachecked 16S rRNA gene database and workbench compatible with ARB. Appl Environ Microbiol. 2006; 72: 5069-72.

20. Ritari J, Salojärvi J, Lahti L, de Vos WM. Improved taxonomic assignment of human intestinal 16S rRNA sequences by a dedicated reference database. BMC Genomics. 2015; 16 (1): 1056. DOI: 10.1186/s12864-015-2265-y.

\section{Литература}

1. Mai E, Buysse DJ. Insomnia: prevalence, impact, pathogenesis, differential diagnosis, and evaluation. Sleep Med Clin. 2008; 3 (2): 167-174. DOI: 10.1016/j.jsmc.2008.02.001.

2. Ohayon MM. Epidemiology of insomnia: what we know and what we still need to learn. Sleep Med Rev. 2002; 6 (2): 97-111. DOI: 10.1053/smrv.2002.0186.

3. Levenson JC, Kay DB, Buysse DJ. The pathophysiology of insomnia. Chest, 2015, 147: 1179-1192. DOI: 10.1378/ chest.14-1617.

4. Rodenbeck A, Hajak G. Neuroendocrine dysregulation in primary insomnia. Rev Neurol (Paris). 2001; 157 (11 Pt 2): S57-61.

5. Forrest CM, Mackay GM, Stoy N, Stone TW, Darlington LG. Inflammatory status and kynurenine metabolism in rheumatoid arthritis treated with melatonin. Br J Clin Pharmacol. 2007; 64 (4): 517-26. DOI: 10.1111/j.1365-2125.2007.02911.x.

6. Hurtado-Alvarado G, Dominguez-Salazar E, Pavon L, VelazquezMoctezuma J, Gomez-Gonzalez B. Blood-brain barrier disruption induced by chronic sleep loss: low-grade inflammation may be the link. JlmmunolRes. 2016; 2016 (4576012): 1-15. DOI: 10.1155/2016/4576012

7. Cryan JF, Dinan TG. Mind-altering microorganisms: the impact of the gut microbiota on brain and behaviour. Nat Rev Neurosci. 2012; 13 (10): 701-712. DOI: 10.1038/nrn3346.
21. Mayer EA. Gut feelings: the emerging biology of gut-brain communication. Nat Rev Neurosci. 2011; 12 (8): 453-66. DOl: 10.1038/nrn3071.

22. Lima-Ojeda JM, Rupprecht R, Baghai TC. «I am I and my bacterial circumstances»: linking gut microbiome, neurodevelopment, and depression. Front Psychiatry. 2017; 8: 153. DOI: 10.3389/ fpsyt.2017.00153.

23. Vuong HE, Yano JM, Fung TC, Hsiao EY. The microbiome and host behavior. Annu Rev Neurosci. 2017; 40: 21-49. DOI: 10.1146/annurev-neuro-072116-031347.

24. Liu B, Lin W, Chen S, et al. Gut Microbiota as a subjective measurement for auxiliary diagnosis of insomnia disorder. Front Microbiol. 2019; 10: 1770. DOI: 10.3389/fmicb.2019.01770.

25. Kim MH, Kang SG, Park JH, Yanagisawa M, Kim CH. Short-chain fatty acids activate GPR41 and GPR43 on intestinal epithelial cells to promote inflammatory responses in mice. Gastroenterology. 2013; 145 (2): 396-406. DOI: 10.1053/j.gastro.2013.04.056.

26. Kim CH, Park J, Kim M. Gut microbiota-derived short-chain fatty acids, T cells, and inflammation. Immune Netw. 2014; 14 (6): 277-88. DOI: 10.4110/in.2014.14.6.277.

27. Mezzatesta ML, Gona F, Stefani S. Enterobacter cloacae complex: clinical impact and emerging antibiotic resistance. Future Microbiol. 2012; 7: 887-902. DOI: 10.2217/fmb.12.61.

28. Chen CQ, Fichna J, Bashashati M, Li YY, Storr M. Distribution, function and physiological role of melatonin in the lower gut. World J Gastroenterol. 2011; 17: 3888-98. DOI: 10.3748/wjg. v17.i34.3888.

29. Park YS, Kim SH, Park JW, et al. Melatonin in the colon modulates intestinal microbiota in response to stress and sleep deprivation. Intest Res. 2020; 18 (3): 325-36. DOI: 10.5217/ir.2019.00093.

30. Zielinski MR, Kim Y, Karpova SA, McCarley RW, Strecker RE, Gerashchenko D. Chronic sleep restriction elevates brain interleukin-1 beta and tumor necrosis factor-alpha and attenuates brain-derived neurotrophic factor expression. Neurosci Lett. 2014; 580: 27-31. DOI: 10.1016/j.neulet.2014.07.04.

31. Patel SR, Zhu X, Storfer-lsser A, et al. Sleep duration and biomarkers of inflammation. Sleep. 2009; 32 (2): 200-4. DOI: 10.1093/sleep/32.2.200.

32. Juste $\mathrm{C}$, Kreil DP, Beauvallet $\mathrm{C}$, et al. Bacterial protein signals are associated with Crohn's disease. Gut. 2014; 63 (10): 1566-77. DOI: 10.1136/gutjnl-2012-303786.

33. Zhang J, Guo Z, Xue Z, et al. A phylo-functional core of gut microbiota in healthy young Chinese cohorts across lifestyles, geography and ethnicities. ISME J. 2015; 9 (9): 1979-90. DOI: 10.1038/ismej.2015.11.

8. Macpherson AJ, Harris NL. Interactions between commensal intestinal bacteria and the immune system. Nat Rev Immunol. 2004; 4 (6): 478-85. DOl: 10.1038/nri1373.

9. Thaiss CA, Levy M, Korem T. Microbiota diurnal rhythmicity programs host transcriptome oscillations. Cell. 2016; 167 (6): 1495-510.e12. DOI: 10.1016/j.cell.2016.11.003.

10. Reynolds AC, Paterson JL, Ferguson SA, Stanley D, Wright KP Jr, Dawson D. The shift work and health research agenda: considering changes in gut microbiota as a pathway linking shift work, sleep loss and circadian misalignment, and metabolic disease. Sleep Med Rev. 2017; 34: 3-9. DOI: 10.1016/j.smrv.2016.06.009.

11. Jackson ML, Butt $H$, Ball M, Lewis DP, Bruck D. Sleep quality and the treatment of intestinal microbiota imbalance in chronic fatigue syndrome: a pilot study. Sleep Sci. 2015; 8 (3): 124-33. DOI: 10.1016/j.slsci.2015.10.001.

12. Poroyko V, Carreras A, Khalyfa A, et al. Chronic Sleep Disruption Alters Gut Microbiota, Induces Systemic and Adipose Tissue Inflammation and Insulin Resistance in Mice. Sci Rep. 2016; 6: 35405. DOI: 10.1038/srep35405.

13. Smith RP, Easson C, Lyle SM, et al. Gut microbiome diversity is associated with sleep physiology in humans. PLoS ONE. 2019; 14 (10): e0222394. Available from: https://doi.org/10.1371/ journal. pone.0222394/ 
14. Li Y, Zhang B, Zhou Y, Wang D, et al. Gut Microbiota Changes and Their Relationship with Inflammation in Patients with Acute and Chronic Insomnia. Nat Sci Sleep. 2020; 12: 895-905. Available from: https://doi.org/10.2147/NSS.S271927.

15. American Academy of Sleep Medicine. International classification of sleep disorders: Diagnostic and coding manual. Westchester, III.: American Academy of Sleep Medicine, 2014.

16. Buysse DJ, Reynolds CF, Monk TH, et al. The Pittsburgh sleep quality index: a new instrument for psychiatric practice and research. Psychiat Res. 1989; 28: 193-213.

17. Mitra S, Forster-Fromme K, Damms-Machado A, et al. Analysis of the intestinal microbiota using SOLiD16S rRNA gene sequencing and SOLiD shotgun sequencing. BMC Genomics. 2013; 14 (5): 16.

18. Caporaso JG, Kuczynski J, Stombaugh J, et al. QIIME allows analysis of high-throughput community sequencing data. Nat Methods. 2010; 7 (5): 335-36. DOI: 10.1038/ nmeth.f.303.

19. DeSantis, TZ, Hugenholtz P, Larsen N. Greengenes, a chimerachecked 16S rRNA gene database and workbench compatible with ARB. Appl Environ Microbiol. 2006; 72: 5069-72.

20. Ritari J, Salojärvi J, Lahti L, de Vos WM. Improved taxonomic assignment of human intestinal 16S rRNA sequences by a dedicated reference database. BMC Genomics. 2015; 16 (1): 1056. DOI: 10.1186/s12864-015-2265-y.

21. Mayer EA. Gut feelings: the emerging biology of gut-brain communication. Nat Rev Neurosci. 2011; 12 (8): 453-66. DOI: 10.1038/nrn3071.

22. Lima-Ojeda JM, Rupprecht R, Baghai TC. «I am I and my bacterial circumstances»: linking gut microbiome, neurodevelopment, and depression. Front Psychiatry. 2017; 8: 153. DOI: 10.3389/ fpsyt.2017.00153.

23. Vuong HE, Yano JM, Fung TC, Hsiao EY. The microbiome and host behavior. Annu Rev Neurosci. 2017; 40: 21-49. DOl: 10.1146/annurev-neuro-072116-031347.

24. Liu B, Lin W, Chen S, et al. Gut Microbiota as a subjective measurement for auxiliary diagnosis of insomnia disorder. Front Microbiol. 2019; 10: 1770. DOI: 10.3389/fmicb.2019.01770.

25. Kim MH, Kang SG, Park JH, Yanagisawa M, Kim CH. Short-chain fatty acids activate GPR41 and GPR43 on intestinal epithelial cells to promote inflammatory responses in mice. Gastroenterology. 2013; 145 (2): 396-406. DOI: 10.1053/. gastro.2013.04.056.

26. Kim CH, Park J, Kim M. Gut microbiota-derived short-chain fatty acids, T cells, and inflammation. Immune Netw. 2014; 14 (6): 277-88. DOI: 10.4110/in.2014.14.6.277.

27. Mezzatesta ML, Gona F, Stefani S. Enterobacter cloacae complex: clinical impact and emerging antibiotic resistance. Future Microbiol. 2012; 7: 887-902. DOI: 10.2217/fmb.12.61.

28. Chen CQ, Fichna J, Bashashati M, Li YY, Storr M. Distribution, function and physiological role of melatonin in the lower gut. World J Gastroenterol. 2011; 17: 3888-98. DOI: 10.3748/wjg. v17.i34.3888.

29. Park YS, Kim SH, Park JW, et al. Melatonin in the colon modulates intestinal microbiota in response to stress and sleep deprivation. Intest Res. 2020; 18 (3): 325-36. DOI: 10.5217/ir.2019.00093.

30. Zielinski MR, Kim Y, Karpova SA, McCarley RW, Strecker RE, Gerashchenko D. Chronic sleep restriction elevates brain interleukin-1 beta and tumor necrosis factor-alpha and attenuates brain-derived neurotrophic factor expression. Neurosci Lett. 2014; 580: 27-31. DOI: 10.1016/j.neulet.2014.07.04.

31. Patel SR, Zhu X, Storfer-Isser A, et al. Sleep duration and biomarkers of inflammation. Sleep. 2009; 32 (2): 200-4. DOI: 10.1093/sleep/32.2.200.

32. Juste $\mathrm{C}$, Kreil DP, Beauvallet $\mathrm{C}$, et al. Bacterial protein signals are associated with Crohn's disease. Gut. 2014; 63 (10): 1566-77. DOI: 10.1136/gutjnl-2012-303786.

33. Zhang J, Guo Z, Xue Z, et al. A phylo-functional core of gut microbiota in healthy young Chinese cohorts across lifestyles, geography and ethnicities. ISME J. 2015; 9 (9): 1979-90. DOI: 10.1038/ismej.2015.11. 